\title{
School-based interventions on physical inactivity as a risk factor of chronic diseases of lifestyle: A review
}

\author{
J. FRANTZ AND M. CHANDEU
}

University of the Western Cape, Private Bag X17, Bellville 7530, Cape Town, South Africa. EMail: jfrantz@uwc.ac.za

\begin{abstract}
School -based health education programmes are important in focussing on risk factors for chronic disease of lifestyle (CDL) among young people. The school as a setting can be used to assist learners to make informed decisions regarding health risk behaviours. In this article, research relating to school based interventions was reviewed by addressing physical inactivity as a risk factor for chronic diseases of lifestyle among young people. The literature search included data bases such as Pubmed, CINAHL, Ebscohost for the period of 1998-2008. Articles were assessed for methodological quality and according to the RE-AIM framework. Two assessors favourably rated the quality of the articles reviewed. Of the total number of articles identified, 60 were selected for further investigation but 26 were excluded after the first review and a further 21 following evaluation of the methodological quality and considering the REAIM framework. Thus, 13 articles were eventually reviewed and included as they had a moderate to high score in both methodological assessment and REAIM framework. Results were presented according to the RE-AIM framework and a narrative summary is provided. It was concluded that currently very few interventions were having the desired impact on behavioural change over a period of time and the targeted populations could not sustain the interventions. Thus, as health educators and promoters of behavioural change, it is important that the impact and sustainability of intervention programmes are prioritised.
\end{abstract}

Keywords: Intervention, schools, youth, RE-AIM, systematic review.

\section{How to cite this article:}

Frantz, J. \& Chandeu, M. (2011). School-based interventions on physical inactivity as a risk factor of chronic diseases of lifestyle: A review. African Journal for Physical, Health Education, Recreation and Dance, June (Supplement), 39-48.

\section{Introduction}

Chronic diseases of lifestyle (CDL) and its risk factors are on the increase worldwide. It is fast becoming a public health concern throughout the world and is compounded by factors such as obesity (Mendes et al. 2007). Children and adolescents have not escaped the epidemic of chronic diseases. According to research, many health risk behaviours are acquired during adolescence and continue into adulthood (Rowland, 1996). Since today's youth are adults of the future societies it is important to ensure that prevention programmes for CDL focus on health risk behaviours of the youth. The health risk behaviours that need monitoring in the prevention of chronic diseases include diet, 
drinking alcohol, physical inactivity and smoking as these have been identified as preventable risk factors. According to Catford (2004) health outcomes are likely to be optimal when good health is promoted throughout life. Health promotion strategies focussing on the risk factors of CDL, such as physical inactivity early in life has the potential for a major impact on the health and well being of the youth later in life (CDC, 1996).

The World Health Organisation (WHO) introduced a stepwise framework to monitor the escalating demands of chronic diseases (Bonita et al., 2001). This framework consists of three phases which include a sequential process, starting with gathering questionnaire-based data on key risk factors (Step 1), then moving on to taking simple physical and biomedical measurements (Step 2), followed by implementation of prevention programmes (Step 3). According to Epping-Jordan et al., (2005) the stepwise framework is a flexible and practical approach to address the health needs of a country and implement evidence-based disease prevention control. The implementation of prevention programmes is in phase three of the stepwise framework. However, there exists a gap in the evaluation of evidence-based interventions to inform practice. It has been stated that interventions can occur in various settings, but should have a common goal. Schools have for many years been recognised as an important setting for health education. According to Nutbeam (2000:259), "education has been essential in the promotion and prevention of disease". Thus, the implementation of health education or intervention programmes in the school setting is an important component of disease prevention. However, Peters et al., (2009), underscored that behavioural change does not necessarily flow from improved knowledge about risk factors for CDL, as is evident in the increased health risk behaviours among youth (Reddy et al., 2010). In the South African setting, the Youth Risk Behaviour Survey (YRBS) was conducted in 2002 and 2008. The 2008 results found a prevalence rate of $20 \%$ for overweight among high school learners compared to $17 \%$ in 2002 . In addition, in $2002,26 \%$ of the participants did not participate in physical activity at the time of the study and $42 \%$ had participated in no or insufficient physical activity (Reddy et al., 2010). Based on these findings, one of the recommendations from the YRBS (Reddy et al., 2010) was, "At least one in two learners is not undertaking sufficient exercise to achieve a health benefit. This coupled with the emerging overweight and obesity picture does not bode well for this cohort of learners. A co-ordinated strategy addressing sports, recreation, and exercise for health benefit needs to be promoted in order to reduce the associated risks mentioned above. Such a programme needs to be implemented in a systematic and co-ordinated manner with measurable outcomes that will influence the health of the learners and their families". In order to achieve this recommendation from the YRBS (2008), it is important to review current literature on strategies to promote physical activity and highlight the challenges to prevent similar errors. 
Thus the aim of this systematic review was to analyse literature relating to school- based interventions addressing physical inactivity as a risk factor for CDL among young people. The objectives were to highlight the (i) types of school interventions used to address physical activity as a risk factor for chronic diseases of lifestyle; (ii) theories used to design the interventions; (iii) outcomes of the school interventions used and (iv) formulate an evidence base for schoolbased interventions addressing physical activity as a risk factor for CDL. The review is structured around the Reach, Efficacy, Adoption, Implementation and Maintenance (RE-AIM) framework which was designed to assist in assessing the translation of research into practice for health promotion interventions (Glasgow, Vogt \& Boles, 1999). The studies did not necessarily have to mention the REAIM framework but needed to address one of the components mentioned above.

\section{Methods}

A systematic approach to the review was adopted and reported in a narrative form.

Criteria for the review

All levels of evidence were considered with more emphasis on experimental or quasi-experimental studies that used some type of comparison or control condition. Studies reporting pre- and post-test results of single interventions were also included.

\section{Search Strategy}

Data bases such as Pubmed, CINAHL, Ebscohost were searched for the period 1998-2008. The criteria for inclusion into the study were: (i) publication in English language; (ii) publication dates between 1998 and 2008; (iii) target population in school settings; (iv) school-based interventions addressing physical inactivity as a risk factor for chronic diseases of lifestyle. Manual searching of reference lists were also undertaken. Search terms were constructed after some review of relevant literature which included risk factors for chronic diseases, school-based intervention programs/programmes, physical inactivity, youth/adolescents, prevention.

\section{Methods of the review}

The initial search was conducted by one researcher and abstracts of articles were reviewed by two reviewers. Full texts of all selected articles were then retrieved. A data extraction sheet was subsequently designed (Table 1) to identify the relevant information such as author, date, type of intervention, population and outcomes. The level of evidence according to the RE-AIM framework and 


\section{Frantz and Chandeu}

quality of evidence were assessed by each reviewer independently. The quality assessment of the articles was done using the data extraction and quality assessment form by Kaaya et al. (2002). Each article was allocated a score out of 40 and overall rating was expressed as a percentage of the maximum score (Kaaya et al., 2002). The rating score had three levels: weak $(\leq 50 \%)$; moderate $(51-80 \%)$ and strong $(>80 \%)$. In addition, articles were also coded using the RE-AIM criteria suggested by Dzewaltowski et al., (2004). Studies were excluded if one component of the assessment was weak $(<50 \%)$ and if physical activity was not used as an outcome of the intervention. A narrative synthesis of the included studies was done.

Table 1: Data extraction information of included articles

\begin{tabular}{|c|c|c|c|c|}
\hline Author & $\begin{array}{l}\text { Hierarchy of } \\
\text { design }\end{array}$ & Intervention & Population & Outcome \\
\hline $\begin{array}{l}\text { McMurray } \\
\text { et al. } \\
(2002)\end{array}$ & $\begin{array}{l}\text { Experimental } \\
\text { design }\end{array}$ & $\begin{array}{l}\text { 8-week interventions } \\
\text { focussing on exercise ( } 30 \\
\text { min } 3 \text { times a week), } \\
\text { education ( } 2 \text { lessons per } \\
\text { week) and a combination }\end{array}$ & $\begin{array}{l}5 \text { schools and within } \\
\text { each school there } \\
\text { was } 1 \text { control group } \\
\text { and } 3 \text { intervention } \\
\text { groups: middle } \\
\text { school aged } \\
\text { adolescents: } 1140\end{array}$ & $\begin{array}{l}\text { Improved } \\
\text { physical activity } \\
\text { and improved } \\
\text { knowledge about } \\
\text { weight control } \\
\text { and blood } \\
\text { pressure }\end{array}$ \\
\hline $\begin{array}{l}\text { Neumark- } \\
\text { Sztainer et } \\
\text { al. }(2003)\end{array}$ & $\begin{array}{l}\text { Experimental } \\
\text { design }\end{array}$ & $\begin{array}{l}\text { Intervention focussed on } \\
\text { physical activity, social } \\
\text { support and nutritional } \\
\text { guidance }\end{array}$ & $\begin{array}{l}3 \text { intervention ( } 89 \\
\text { girls)and } 3 \text { control } \\
\text { schools (112 girls) }\end{array}$ & $\begin{array}{l}\text { Improved impact } \\
\text { on physical } \\
\text { activity, eating } \\
\text { habits and self } \\
\text { image }\end{array}$ \\
\hline $\begin{array}{l}\text { Jamner- } \\
\text { Schneider } \\
\text { et al. } \\
(2004)\end{array}$ & $\begin{array}{l}\text { Quasi- } \\
\text { experimental } \\
\text { design }\end{array}$ & $\begin{array}{l}4 \text { month intervention } \\
\text { included physical activity } \\
\text { and education on benefits } \\
\text { of physical activity ( } 5 \text { days } \\
\text { per week for } 60 \text { min) }\end{array}$ & $\begin{array}{l}2 \text { high schools: } 1 \\
\text { school was the } \\
\text { control and the other } \\
\text { the intervention }\end{array}$ & $\begin{array}{l}\text { Improved } \\
\text { physical fitness, } \\
\text { physical activity } \\
\text { and knowledge }\end{array}$ \\
\hline $\begin{array}{l}\text { Dishman } \\
\text { et al. } \\
(2004)\end{array}$ & $\begin{array}{l}\text { Experimental } \\
\text { design }\end{array}$ & $\begin{array}{l}2 \text { year physical activity } \\
\text { intervention: } 60-90 \text { minute } \\
\text { sessions }\end{array}$ & $\begin{array}{l}24 \text { high schools. } \\
\text { Grade } 8 \text { and } 9 \\
\text { learners. } 1038 \text { girls } \\
\text { in the control group } \\
\text { and } 1049 \text { in the } \\
\text { intervention group } \\
13-15 \text { year olds }\end{array}$ & $\begin{array}{l}\text { Improve self- } \\
\text { efficacy, goal } \\
\text { setting, physical } \\
\text { activity }\end{array}$ \\
\hline $\begin{array}{l}\text { Pate et al. } \\
(2005) .\end{array}$ & $\begin{array}{l}\text { Experimental } \\
\text { design }\end{array}$ & $\begin{array}{l}2 \text { year physical activity } \\
\text { intervention: } \\
60-90 \text { minute sessions } \\
6 \text { components: } \\
\text { PE, health education, } \\
\text { school environ, staff health } \\
\text { promotion, school health } \\
\text { services, comm. } \\
\text { involvement }\end{array}$ & $\begin{array}{l}24 \text { high schools: } \\
2744 \text { girls in grade } 8 \\
\text { and } 9\end{array}$ & $\begin{array}{l}\text { Improved } \\
\text { participation in } \\
\text { physical activity } \\
\text { by girls }\end{array}$ \\
\hline $\begin{array}{l}\text { Naylor et } \\
\text { al. (2006) }\end{array}$ & $\begin{array}{l}\text { Non- } \\
\text { experimental } \\
\text { design }\end{array}$ & $\begin{array}{l}11 \text { month physical activity } \\
\text { programme with weekly } \\
\text { activities. } 150 \text { minutes of } \\
\text { moderate intensity activity } \\
\text { per week }\end{array}$ & $\begin{array}{l}10 \text { schools, grade } 4-6 \\
\text { learners and teachers } \\
91 \text { teachers and } 10 \\
\text { schools with } 300 \\
\text { learners }\end{array}$ & $\begin{array}{l}\text { Positive changes } \\
\text { in learners and } \\
\text { school } \\
\text { environment as it } \\
\text { relates to physical } \\
\text { activity }\end{array}$ \\
\hline
\end{tabular}




\section{Zahner et Experimental 3 year duration physical al. (2006) design activity intervention: 45 minutes per session $\mathrm{x} 2$ weekly}

$\begin{array}{ll}\text { Ward et } & \text { Quasi- } \\ \text { al. (2006) } & \begin{array}{l}\text { experimental } \\ \text { design }\end{array}\end{array}$

Haerens et Experimental al. (2007) design

Pate et al. (2007)

Jiang et al. (2007).

$\begin{array}{ll}\text { Schneider } & \text { Quasi- } \\ \text { et al. } & \text { experimental } \\ (2008) & \text { design }\end{array}$

Webber et Experimental al. (2008) design
2 year physical activity intervention providing support for teachers and participants

Physical activity and diet intervention. Work group met once every 3 months. An hour of physical activity per day was encouraged. Intervention was implemented by school staff

$\begin{array}{ll}\text { Quasi } & 1 \text { semester physical } \\ \text { experimental } & \text { education intervention } \\ \text { design } & \end{array}$

Experimental design activity. Programme ran
20 week physical activity and nutrition education program. 1 education lecture per semester to parents. 10 obesity themes were discussed over 20 weeks -1 theme every 2 weeks

9 month physical activity intervention. 5 days/week for 60 minutes ( $40 \mathrm{~min}$ of activity)

\section{Promoting physical} over a period of 3 years. Six theory lessons for each of the $7^{\text {th }}$ and $8^{\text {th }}$ grade learners. $50 \%$ of PE class time was dedicated to promoting physical activity
15 schools, grades 1- Increased

5. 530 children.

9 schools in the intervention group and 6 schools in the control group 6-12 year olds 24 schools with $12 \quad$ Improved controls schools and physical activity 12 intervention schools, $9^{\text {th }}$ grade learners

15 schools of $7^{\text {th }}$ and $8^{\text {th }}$ graders was randomly assigned to 3 conditions physical activity, physical fitness and decreased body fat and knowledge

Increased physical activity behaviour

31 middle schools Involvement in and 24 high school PE resulted in female learners. Thus 5423 Grade 8improved involvement in 12 learners VPA and MPA 5 primary schools. Improved 2425 children with knowledge 1029 children in the related to intervention group (2 physical activity schools) and 1396 and nutrition children in the control group ( 3 schools)

146 grade 10 and 11 Improved learners. 79 in the cardiovascular intervention group and 67 in the comparison group

6 schools in 6 districts for grade6 $(\mathrm{n}=1721)$, grade 7 $(\mathrm{n}=3504)$ and grade 8 learners $(\mathrm{n}=3502)$ fitness but no change to physical selfconcept To improve behavioural skills and influence physical activity participation 


\section{Frantz and Chandeu}

\section{Results}

A total of more than 200 titles were identified and assessed.

Table 2: Summary of the findings according to the REAIM model

\begin{tabular}{ll}
$\begin{array}{l}\text { RE-AIM Model } \\
\text { Component }\end{array}$ & Definition \\
\hline Reach & $\begin{array}{l}\text { An individual measure of the } \\
\text { percentage and risk } \\
\text { characteristics of people who } \\
\text { are affected by a policy or } \\
\text { program. }\end{array}$
\end{tabular}

Application to the Review

There is definite evidence that school based interventions are targeting physical inactivity as a risk factor among young people. In the current review most of the studies have been conducted in the USA, Canada and Europe with no evidence of studies reportedly conducted in developing countries.

$\begin{array}{ll}\text { Efficacy } & \text { An individual measure of } \\ \text { positive and negative } \\ \text { consequences of a program } \\ \text { for four types of outcomes: } \\ \text { behavioral, physiological, } \\ \text { and satisfaction of } \\ \text { participants. }\end{array}$

Adoption

Implementation A measure of the extent to

An organization- and the proportion and (e.g. school) that adopt a given program. which an intervention is
implemented as intended.

which an intervention is
implemented as intended.

Maintenance community-level measure of representativeness of settings

An over time and becomes a relatively stable, enduring part of behavior.
Evidence of interventions used to track physical inactivity as a risk factor is evident in the studies and the development of interventions based on theories indicate that there is definitely an awareness that interventions need to incorporate various factors that will influences physical activity participation that includes personal, behavioural and environmental change

Evidence that a policy was instituted in the school settings was not evident always in the studies reviewed.

Evidence of intended interventions and implementation strategies were clearly described and explanations of the interventions in terms of content, time frames and outcomes were described. A variety of interventions were used in the different studies, however all of the studies had several components included as part of the intervention which addressed both environmental and personal factors of the participants. The length of the interventions varied from 2 months ( 8 weeks) to 24 months ( 2 years). The average length of a time for an intervention was 14.2 months.

Evidence of efforts to sustain and evaluate the interventions were not commonly reported on in the studies with very few studies reporting on follow-up information 
Of the total number of articles identified, 60 were selected for further investigation.

Several articles $(\mathrm{N}=26)$ were then excluded based on the outcome of the intervention not having included physical activity. From the articles retrieved, 34 studies were included in the review based on meeting the inclusion criteria. Following evaluation of the methodological quality and considering the REAIM framework, 21 articles were excluded on account of low scores. Thus the final number of articles used in this review was 13 as they had a moderate to high score in both methodological assessment and REAIM framework. Results are presented according to the RE-AIM framework (Table 2).

Theories commonly used to guide the interventions included the Social Cognitive Theory (Dishman et al., 2004; Ward et al., 2006), Theory of planned behaviour (Webber et al., 2008), Operant learning theory (Webber et al., 2008) and the organisational change theory (Webber et al., (2008). In addition, studies were also guided by the Comprehensive School Health Programme as well as the Health Promoting Schools Concept (Naylor et al., 2006).

Although all the studies identified physical inactivity as a risk factor for chronic diseases of lifestyle $(\mathrm{N}=13)$, only three of the studies (Hearens et al., 2007; Naylor et al., 2006; Pate et al., 2005) listed improvement in physical activity as the only outcome measure. Other outcome measures considered in the other studies included self-efficacy (Dishman et al., 2004), cardiovascular fitness (Schneider et al., 2008), physical fitness (Zahner et al., 2006; Jamner- Schneider et al., 2004), anthropometric measurements (Zahner et al., 2006, McMurray et al., 2002) and self-image (Neumark-Sztainer et al., 2003.

\section{Discussion}

This review has systematically identified school based-interventions addressing physical inactivity and the effects of the school based-interventions based using the RE-AIM framework. It is evident from the literature that several school based interventions have been attempted. The RE-AIM framework allows one to determine the effectiveness and impact of the intervention at individual, institution and community level (Glasgow et al., 1999). From the review it is clear that although the interventions were found to be methodologically sound, however, when systematically considered for their strengths and weakness, they were found to have shortcomings. Some of the main shortcomings identified according to the RE-AIM framework were the success of the intervention at institution and community level when assessing adoption, impact and maintenance. If successful interventions are to be implemented the use of the RE-AIM framework can assist various stakeholders to understand the broad 
array of issues that an effective programme must address in order to have lasting impact.

The review highlights that school-based interventions can improve the health of young people by initiating changes in physical, economic, and social environments. The interventions that were most effective in improving physical activity were based on theoretically-driven approaches (Resnicow et al., 2002). Their success is attributed in part to the assumption that theory is thought to provide an effective framework for understanding the mediators and moderators of health behaviour. For example, the Theory of Planned Behaviour has been used as a conceptual framework in some interventions to improve physical activity. This theory uses a person's individual motivational factors to predict the performance of a specific behaviour. However, according to Brug, Oenema and Ferreira (2005) although the application of theory should improve the likelihood of effectiveness of interventions, "most of the theories that are applied in behavior nutrition and physical activity interventions provide information on what needs to be changed to promote healthy behavior but not on how change can be induced".

In addition, when evaluating the effects of the intervention using the RE-AIM framework it is evident that there is a lack of studies including a follow-up period in the planning of their interventions they would be able to report on the aspects of adoption and maintenance. In addition, when reporting on the intervention it is important that follow-up information is also provided in order to be able to measure future adoption and maintenance of intervention programmes. This will assist future researchers in understanding whether interventions have impacted on behavioural change which has been identified as a problem in the literature.

\section{Acknowledgement}

This article is based on work supported by the National Research Foundation. Any opinion, findings and conclusions or recommendations expressed in this article are those of the authors and therefore the NRF does not accept any liability regarding the content of the work.

\section{References}

Bonita, R., de Courten, M., Dwyer, T., Jamrozik, K. \& Winkelmann, R. (2001). Surveillance of risk factors for noncommunicable diseases: The WHO stepwise approach. Geneva: World Health Organization.

Brug, J., Oenema, A. \& Ferreira, I. (2005). Theory, evidence and intervention mapping to improve behaviour nutrition and physical activity interventions. International Journal of Behavioral Nutrition and Physical Activity, 2:2 doi:10.1186/1479-5868-2-2.

Catford, J. (2004). Health promotion's record card-how principled are we twenty years on? Health Promotion International, 19, 1-4. 
Centres for Disease Control and Prevention (1996). Physical activity and health: A report of the Surgeon General. Atlanta: U.S. Department of Health and Human Services.

Dishman, R.K., Motl, R.W., Saunders, R., Felton, G., Ward, D., Dowda, M., \& Pate, R. (2004). Self-efficacy partially mediates the effect of a school-based physical activity intervention among adolescent girls. Preventive Medicine, 38, 628-636.

Dzewaltowski, D., Esabrooks, P., Klesges, L., Bull, S. \& Glasgow, R. (2004). Behaviour change intervention research in community settings: How generalisable are the results? Health Promotion International, 19(2), 235-245.

Epping-Jordan, J., Galea, G., Tukuitonga, C. \& Beaglehole, R. (2005). Preventing chronic disease: taking stepwise action. Lancet, 366(9497), 1667-71.

Glasgow, R., Vogt, T. \& Boles, S (1999). Evaluating the impact of health promotion interventions: the RE-AIM framework. American Journal of Public Health, 89 (9), 1322-1327.

Haerens, L., De Bourdeaudhuij, I., Maes, L., Cardon, G. \& Deforche, B. (2007). School based randomised controlled trial of a physical activity intervention among adolescents. Journal of Adolescent Health, 40, 258-265.

Jamner- Schneider, M., Spruijt-Metz, D., Bassin, S. \& Cooper, D. (2004). A controlled evaluation of a school-based intervention to promote physical activity among sedentary adolescent females. Journal of Adolescent Health, 34, 279-289.

Jiang, J., Xia, X., Greiner, T., Wu, G., Lian, G. \& Rosenqvist, U. (2007). The effects of a 3-year obesity intervention in school children in Beijing. Child: Care, Health and Development, 33(5), 641-646.

Kaaya, S., Mukoma, W., Fleisher, A.J. \& Klepp, K. (2002). School based sexual health interventions in sub-Saharan Africa: A review. Social Dynamics. 28, 64-88.

McMurray, R., Harrell, J., Bangdiwala, S., Bradley, C., Deng, S. \& Levine, A. (2002). A schoolbased intervention can reduce body fat and blood pressure in young adolescents. Journal of Adolescent Health, 31, 125-132.

Mendes, S., Fukino, K., Cameron, A., Laing, R., Filipe Jr., A, Khatib, O., Leowski, J. \& Ewen, M. (2007). The availability and affordability of selected essential medicines for chronic diseases in low- and middle-income countries. Bulletin of WHO, 85, 279-288.

Naylor, P., Macdonald, H., Zebedee, J., Reed, K. \& McKay, H. (2006). Lessons learned from Action Schools! BC- An active school model to promote physical activity in elementary schools. Journal of Science and Medicine in Sport, 9, 413-423.

Neumark-Sztainer, D., Story, M., Hannan, P., Stat, M. \& Rex, J. (2003). New Moves: A schoolbased obesity prevention program for adolescent girls. Preventive Medicine, 37, 41-51.

Nutbeam, D. (2000). Health literacy as a public health goal: A challenge for contemporary health education and communication strategies into the $21^{\text {st }}$ century. Health Promotion International, $15(3), 259-267$. 
Pate, R., Ward, D., Saunders, R., Felton, G., Dishman, R. \& Dowda, M. (2005). Promotion of physical activity among high school girls: A Randomised Control Trial. American Journal of Public Health, 95(9), 1582-1587.

Pate, R., Ward, D., O’Neill, J. \& Dowda, M. (2007). Enrolment in physical education is associated with overall physical activity in adolescent girls. Research Quarterly for Exercise and Sport. 78(4), 265-270.

Peters, L.W., Kok, G., Ten Dam, G.T., Buijs, G.J. \& Paulussen, T.G. (2009). Effective elements of school health promotion across behavioural domains: a systematic review. BMC Public Health, 9, 182, doi: 10.1186/1471-2458-9-182.

Reddy, S.P., James, S., Sewpaul, R., Koopman, F., Funani, N.I., Sifunda, S., Josie, J., Masuka, P., Kambaran, N.S. \& Omardien, R.G. (2010). Umthente Uhlaba Usamila - The South African Youth Risk Behaviour Survey 2008. Cape Town: South African Medical Research Council, 2010 http://www.mrc.ac.za/healthpromotion/yrbs_2008_final_report.pdf

Resnicow, K., Braithwaite, R., Dilorio, C. \& Glanz, K. (2002). Applying theory to culturally diverse and unique populations. In K. Glanz, B. Rimer \& F. Lewis (Eds.), Health behavior and health education Theory, research and practice ( $3^{\text {rd }}$ ed.) (pp. 485-509). San Francisco: JosseyBass.

Rowland T. W. (1996). Is there a scientific rational supporting the value of exercise for the present and future cardiovascular health of children? The con argument. Pediatric Exercise Science, 8, 303-309.

Schneider, M., Dunton, G. \& Cooper, D. (2008). Physical activity and physical concept among sedentary adolescent females: An intervention study. Psychology of Sport and Exercise, 9, 1-14.

Ward, D., Saunders, R., Felton, G., Williams, E., Epping, J. \& Pate, R. (2006). Implementation of a school environment intervention to increase physical activity in high school girls. Health Education Research, 21(6), 896-910.

Webber, L., Catellier, D., Lytle, L., Murray, D., Pratt, C., Young, D., Elder, J., Lohman, T., Stevens, J., Jobe, B. \& Pate, R. (2008). Promoting physical activity in middle school girls. Trial of activity for adolescent girls. American Journal of Preventive Medicine, 34(3), 173-184.

YRBS (2008). Youth Risk Behavioural Surveillance System 2008 (On Line). Retrieved February, 09, $2011 \mathrm{http} / / /$ www.mrc.ac.za/healthpromotion/yrbs_2008_final_report.pdf.

Zahner, L., Puder, J., Roth, R., Schmid, M., Guldimann, R., Pühse, U., Knöpfli, M., BraunFahrländer, C., Marti, B. \& Kriemler, S. (2006). A school-based physical activity program to improve health and fitness in children aged 6-13 years. BMC Public Health. 6, 147. doi: 10.1186/1471-2458-6-147. 